Pesq. Vet. Bras. 36(12):1203-1208, dezembro 2016 DOI: $10.1590 / \mathrm{S} 0100-736 \mathrm{X} 2016001200011$

\title{
Computerized electrocardiography in healthy conscious guinea pigs (Cavia porcellus) ${ }^{1}$
}

\begin{abstract}
Ana F.M. Botelho ${ }^{2 *}$, Maira S. de Oliveira², Benito Soto-Blanco ${ }^{2}$ and Marília M. Melo ${ }^{2}$
ABSTRACT.- Botelho A.F.M., Oliveira M.S., Soto-Blanco B. \& Melo M.M. 2016. Computerized electrocardiography in healthy conscious guinea pigs (Cavia porcellus). Pesquisa Veterinária Brasileira 36(12):1203-1208. Departamento de Clínica e Cirurgia Veterinárias, Escola de Veterinária, Universidade Federal de Minas Gerais, Av. Presidente Antônio Carlos 6627, Belo Horizonte, MG 31275-013, Brazil. E-mail: anaflaviamabo@gmail.com

The purpose of this study is to evaluate healthy conscious guinea pigs as a model for electrophysiology assessment and to describe normal electrocardiographic patterns in controlled laboratory environment, establishing the best QT formula for this method. Electrocardiographic recordings of fifty adult conscious guinea pigs were obtained using a computerized electrocardiography. The electrocardiographic measurements of three different tracings were analyzed. The results obtained established normal mean and range values for the parameters: heart rate, waves and intervals of P-QRS-T deflections, as well as the mean cardiac axis. Groups were separated by body weight: group 1 gathered animals with 500-699g and group 2 with animals 700-900g. No differences were found when measurements were compared between groups, showing no significant difference between weight/ body sizes to the electrocardiographic parameters $(\mathrm{P}<0.05)$. The mean corrected QT values (QTc) obtained using diverse formulae were significantly different $(\mathrm{P}<0.05)$, were the most consistent was Van der Water $(\mathrm{QTcV})$. QTcV values were strongly correlated $(\mathrm{r}=98)$ and 95\% confidence interval 185.7 to $195.2 \mathrm{~ms}$.Considering its simplicity and reliability, the QTcV was deemed the most appropriate to be used for the correction of QT interval in conscious guinea pigs.The results of this study also suggest that the values found can be used as reference for the species.
\end{abstract}

INDEX TERMS: Guinea pigs, electrocardiogram, computerized ECG, conscious.

RESUMO-- [Eletrocardiografia computadorizada em cobaios (Cavia porcellus) saudáveis e conscientes.] 0 objetivo desse estudo foi avaliar cobaios hígidos e conscientes como modelos para estudos de eletrofisiologia e descrever os padrões eletrocardiográficos normais em ambiente laboratorial controlado, estabelecendo a melhor fórmula QT para esse método. Gravações eletrocardiográficas de cinquenta cobaios adultos conscientes foram obtidas usando eletrocardiografia computadorizada. As medidas eletrocardiográficas de três trechos diferentes foram analisadas. Os resultados estabeleceram média e desvio padrão para os parâmetros: frequência cardíaca, ondas e intervalos P-QRS-T, assim como

\footnotetext{
${ }^{1}$ Received on February 15, 2016.

Accepted for publication on July 15, 2016.

${ }^{2}$ Departamento de Clínica e Cirurgia Veterinárias, Escola de Veterinária, Universidade Federal de Minas Gerais (UFMG), Av. Presidente Antônio Carlos 6627, Belo Horizonte, MG 31275-013, Brazil. *Corresponding author: anaflaviamabo@gmail.com
}

o eixo cardíaco médio. Grupos foram separados de acordo com o peso: grupo 1 incluiu animais com 500-699g e o grupo 2 animais de 700-900g. Nenhuma diferença foi encontrada quando as medidas foram comparadas entre os grupos, mostrando que não há diferença significativa entre peso/ tamanho corporal com os parâmetros eletrocardiográficos $(\mathrm{p}<0.05)$. As médias corrigidas dos valores do QT (QTc) obtidas usando diferentes fórmulas foram significativamente diferentes $(\mathrm{p}<0.05)$, sendo a mais consistente a de Van der Water (QTcV). Valores de QTcV fortemente correlacionam com o QT ( $\mathrm{r}=98)$, com intervalo de confiança a 95\% de 185.7 a 195.2 ms. Considerando a simplicidade e confiabilidade, o QTcV foi considerado apropriado para correção do intervalo QT em cobaios conscientes. Os resultados do presente estudo também sugerem que os valores encontrados possam ser utilizados como referência para essa espécie.

TERMOS DE INDEXAÇÃO: Cobaios, eletrocardiograma, ECG computadorizado, conscientes. 


\section{INTRODUCTION}

The electrocardiogram (ECG) is a well established important tool in the evaluation of cardiac electrical function and essential in the diagnosis and monitoring of arrhythmias and conduction disturbances (Tilley 1992). The ECG is used in routine examinations and in experimental research for different cardiovascular assessments (Pinto et al. 2010, Oliveira et al. 2014).

Computerized analyses have introduced new opportunities to expand electrophysiology and cardiac arrhythmia studies, especially in small animals, including guinea pigs (Cavia porcellus). Recent advances in small rodent ECG have enabled assessments in conscious unrestrained animals and improved exam interpretation (Farraj et al. 2011). The measurements found in computerized ECG have more accuracy than conventional ECG with larger storage capacity (Camacho et al. 2010, Pinto et al. 2010). Guinea-pigs are a model for electrophysiological and pharmacological investigations (Farraj et al. 2011). In vivo guinea-pig models were studied over the years, both with conscious (Shiotani et al. 2005) and anesthetized animals (Morissette et al. 2013). This model is especially used to evaluate new drugs before they are allowed for commercialization, particularly those with high risk of arrhythmias and/or alterations of QT interval (Tárraga et al. 2000). The QT interval measured in the ECG represents ventricular depolarization and repolarization (Tilley 1992). This variable exhibits an inverse relationship to the heart rate and its measure should be corrected in order to improve utility (Harada et al. 2010). Correction is also important to precisely infer about abnormalities of the ventricular repolarization, which predispose arrhythmias that must be diagnosis as early as possible (Oliveira et al. 2014). QT variation can be associated with drugs; prolongation is often associated to pathologies such as hypertension, whereas short QT can indicate digitalis intoxication and genetic abnormalities (Peng et al. 2006). Different correction formulae are currently been used for determination of QT parameters in guinea pigs, mostly using anaesthetized animals and implanted ECG needles.

Guinea-pigs as models for ECG studies show interesting features that motivate their use. These rodents are easily handled due to their kind nature, they present relatively low costs of acquisition, nutrition and maintenance, and more importantly, most of their ionic channels are similar to those found in human cardiomyocytes (Malkin 1999). They are also more sensitive to cardioactive glycosides than rats and mice, therefore indicated for the investigation of these inotropic agents (Akera et al. 1979).

Animals ECG patterns can be different accordingly to the body weight and fat deposit, causing cardiac changes that can be seen in the ECG (Neto et al. 2010). Therefore the purpose of this study is to evaluate healthy conscious guinea-pig as a model for electrophysiology assessment and to describe normal ECG patterns in controlled laboratory environment using computerized electrocardiography. The aim of the present study was to establish normal range values for the species comparing possible differences between body weight/size. In addition this study compares different QTc correction formulae, Bazett (1920), Fridericia
(1920) and Van de Water et al. (1989), to establish the most suited for conscious guinea pigs.

\section{MATERIALS AND METHODS}

Animals and groups. A total of 50 healthy adult (3-4 months) male guinea pigs (Cavia porcellus) weighing between 500 and $900 \mathrm{~g}$ were selected. The animals were provided by the Experimental Farm of Universidade Federal de Minas Gerais (UFMG) and kept in the Laboratory of Animal Experimentation of Veterinary School (UFMG) in Belo Horizonte, Minas Gerais, Brazil. Each animal was kept in plastic cages ( $36 \times 26 \times 15 \mathrm{~cm})$, under controlled environment, with 12 hours light/dark cycle and room temperature at $25^{\circ} \mathrm{C}$. The guinea pigs had free access to water and food. Animals were allocated into 2 groups according to their weights: group 1 with animals between $500 \mathrm{~g}$ and $699 \mathrm{~g}$; and group 2 containing animals from $700 \mathrm{~g}$ and $900 \mathrm{~g}$.

This study underwent ethical review and was given approval by the Animal Use Committee of University of Minas Gerais, $\mathrm{n}$ 은 $216 / 2014$. Health and welfare were evaluated through clinical examination by a trained veterinary and $2 \mathrm{ml}$ of blood was collected from the jugular vein prior to the experimental period. Samples were collected in microcentrifuge tubes containing $0.005 \mathrm{~mL}$ of a $10 \%$ solution of diamine tetra acetic acid (EDTA) for automated electronic blood count (Poch-100iV Diff ${ }^{\circledR}$ ) to attain mean values for hematologic parameters. Plasma was then obtained to measure creatine kinase (CK-MB), using Bioclin ${ }^{\circledR}$ kit (Table 1). All parameters were considered normal according to Amani et al. (2013) and Zimmerman et al. (2015).

ECG recording. A six-channel electrocardiograph (ECG-PC version $2.07^{\circledR}$-Tecnologia Eletrônica Brasileira (TEB), Belo Horizonte, Minas Gerais, Brazil) was used. The animals were restrained manually under no sedation or anesthesia during the ECG recording. The rodents were placed in a dorsal recumbence position on a wooden table covered with plastic material. The ventral region of the animals was carefully shaved, alcohol was applied, and four alligator clip electrodes were attached to the skin in the forelimbs and hindlimbs (Tilley 1992). All procedures were performed in a quiet room in order to minimize stress.

ECG trace analysis. All ECGs were performed and analyzed by the same veterinary according to standard methods (Tilley 1992). Tracings were recorded in six leads of the frontal plan, with $50 \mathrm{~mm} / \mathrm{s}$ of velocity and sensitivity of $1 \mathrm{~cm}=2 \mathrm{mV}(2 \mathrm{~N})$.

In each tracing 3 segments containing five beats (lead II) were selected for quality (clean baseline with no artifacts) and mean values for heart rate (HR), and amplitude and length of P-QRS-T deflections were determined. The parameters evaluated were: heart rate and cardiac rhythm, duration of the P wave, QRS complex, PR and QT intervals, and amplitude of $P$ waves, $R$ waves and T waves. QT Values were obtained from the following equations: $\mathrm{QTcB}=\mathrm{QT}^{*}(\mathrm{RR})^{1 / 2}$ (Bazett 1920); $\mathrm{QTcF}=\mathrm{QT}^{*}(\mathrm{RR})^{1 / 3}$ (Fridericia 1920) and QTcV = QT + 0.087(1- RR) (Van de Water et al. 1989).

The mean electrical axis (MEA) of ventricular depolarization in the frontal plane was calculated by the vector method using leads I and III (Tilley 1992). The morphology patterns and rhythm were evaluated in every lead, and P-QRS-T measurements were conducted in lead II.

Statistical analysis. All measurements are expressed as mean \pm standard deviation (SD). Non-parametric data were analyzed by Kruskal-Wallis test. Parametric data measurements of waves, intervals and HR were analyzed by means of Tukey Test. The influence of body weight and HR in electrocardiographic variables and the different QT formulas were compared by the Pearson's test (variables normally distributed). In all the analyses differences were considered to significant when $\mathrm{P} \leq 0.05$. 


\section{RESULTS}

The protocol used provided ECG tracings in conscious guinea pigs with high quality, allowing the evaluation of cardiac rhythm and HR, with reliable measurements of waves and intervals (Fig.1). The procedure was well tolerated by the animals, with minimal movements during positioning and electrode placement.

\section{Heart rate}

The mean HR of all animals was 288.4 beats per minute (bpm), with minimum of 191.7 and maximum of 381 (Table 2). The mean HR was not significantly different between groups $(\mathrm{P} \leq 0.05)$, therefore showing no correlation to the size (i.e. body weight) of the animals (Table 3 ).

\section{Rhythm}

Most of the tracings evaluated showed a regular sinus rhythm (84\%), accompanied by wandering pacemaker in $56 \%$ of the cases. Monomorphic isolated ventricular premature complexes were evident in 8 animals, representing 16\% of the tracings (Fig.2). No other rhythms were observed.

\section{$P$ wave}

The $\mathrm{P}$ wave (atrial depolarization) duration range on lead II was from 37.33 to $50.25 \mathrm{~ms}$, with minimum of 30 and maximum of $60 \mathrm{~ms}$. This parameter was not significantly different between groups showing no correlation to the size (i.e. body weight) of the animals $(\mathrm{P} \leq 0.05)$ (Table 2 ). The wave amplitude range from $0.04 \mathrm{mV}$ to $0.10 \mathrm{mV}$, with no significant difference between groups $(\mathrm{P} \leq 0.05)$ (Table 3 ). The P wave was always positive on lead I, II and aVF. And predominantly positive in lead III.

\section{PR interval}

On lead II, PR interval ranged from 54.35 to $77.55 \mathrm{~ms}$, with mean of $65.95 \mathrm{~ms}$ (Table 2). This parameter was not significantly different between groups showing no correlation to the size (i.e. body weight) of the animals $(\mathrm{P} \leq 0.05)$ (Table 3).

\section{QRS complex}

The QRS complex length ranged from 52.72 to $74.78 \mathrm{~ms}$ (Table 2). This parameter was not significantly different between groups $(\mathrm{P} \leq 0.05)$ showing no correlation to the size (i.e. body weight) of the animals (Table 3 ).

In lead II, the $\mathrm{R}$ wave amplitude ranged from 0.09 to $0.41 \mathrm{mV}$. This parameter was also not significantly different between groups $(\mathrm{P} \leq 0.05)$, showing no correlation to the size (i.e. body weight) of the animals (Table 3). The QRS complexes showed predominantly qRs morphology while only $6 \%$ of the them had RS morphology.

\section{ST segment}

The ST segment in lead II was isoeletric in most cases, ranging from -0.5 to $0.1 \mathrm{mv}$ with no significant difference between groups $(\mathrm{P} \leq 0.05)$ (Table 3$)$.

\section{T wave}

The range of $\mathrm{T}$ wave in lead II in amplitude varied from 0.04 to $0.08 \mathrm{mV}$, with means of $0.06 \mathrm{mV}$ (Table2). This parameter was not significantly different between groups (Table 3) showing no correlation to the size (i.e. body weight) of the animals $(\mathrm{P} \leq 0.05)$.

In lead II, morphology was mainly positive presenting only one biphasic wave. In leads I, avF and avL T wave was always positive. On the other hand in leads III and avR, T wave was mainly negative.

\section{QT interval and correction formulas}

QT interval duration was 123.9, ranging from 107.7 to $140.1 \mathrm{~ms}$, on lead II (Table 2), with no relation to the body weight $(\mathrm{P} \leq 0.05)$ (Table 4). A high correlation was detected

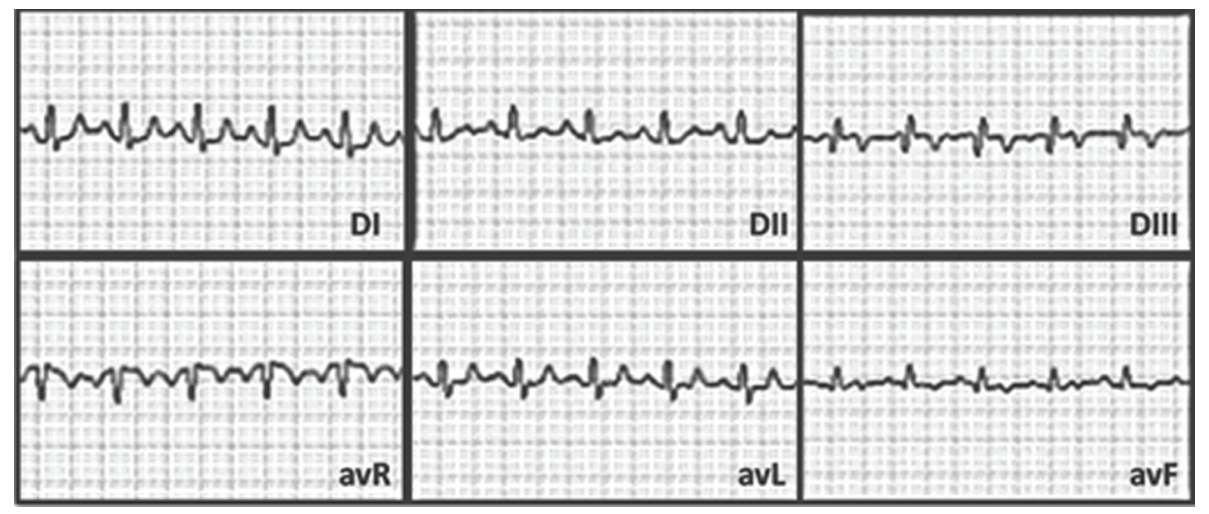

Fig.1. Normal electrocardiographic tracings of a healthy adult conscious guinea pig (Cavia porcellus) using a computerized ECG. Tracings were recorded in six derivations of the frontal plan, with $50 \mathrm{~mm} / \mathrm{s}$ of velocity and sensitivity of $1 \mathrm{~cm}=2 \mathrm{mV}(2 \mathrm{~N})$.

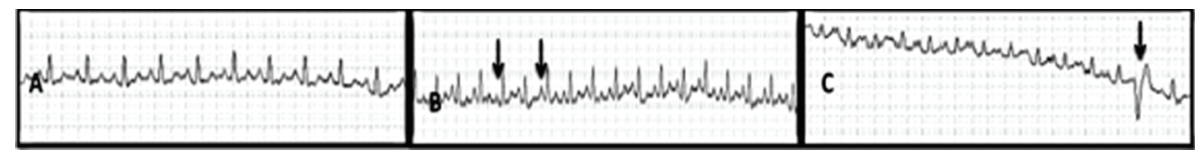

Fig.2. Electrocardiographic tracings of three adult conscious guinea pig (Cavia porcellus) using a computerized ECG. Tracings were recorded in six derivations of the frontal plan, with $50 \mathrm{~mm} / \mathrm{s}$ of velocity and sensitivity of $1 \mathrm{~cm}=2 \mathrm{mV}(2 \mathrm{~N})$. (A) Normal sinus rhythm; (B) wandering pacemaker; C-ventricular premature complexes. Arrows indicating the ECG alterations. DII, 50mm/s, $2 \mathrm{mV}$. 
Table 1. Mean values and standard deviation (SD) of hematological examination and creatine kinase MB fraction (CK-MB, U/L) from adult guinea pigs (Cavia porcellus) prior to the electrocardiographic exam

Parameter
Erythrocytes $\left(\times 10^{6} / \mu \mathrm{L}\right)$
Packed cell volume $(\mathrm{PCV}, \%)$
Hemoglobin $(\mathrm{g} / \mathrm{dL})$
Mean corpuscular volume $(\mathrm{MCV}, \mathrm{fL})$
Mean corpuscular hemoglobin $(\mathrm{MCH}, \%)$
Mean corpuscular hemoglobin
concentration $(\mathrm{MCHC}, \mathrm{g} / \mathrm{dL})$
Platelets $\left(\mathrm{x} 10^{3} / \mu \mathrm{L}\right)$
Total leukocytes $(/ \mu \mathrm{L})$
Lymphocytes $(\%)$
Heterophilus $(\%)$
CK-MB $(\mathrm{U} / \mathrm{L})$

Mean \pm SD
$5.09 \pm 0.04$
$41.20 \pm 2.97$
$14.20 \pm 1.06$
$82.00 \pm 1.99$
$27.90 \pm 0.66$
$34.00 \pm 0.76$
$211.00 \pm 25.4$
$9.20 \pm 4.74$
$37.10 \pm 3.35$
$55.37 \pm 6.15$
$225.88 \pm 98.40$

Table 2. Mean, standard deviation, minimum and maximum values of the electrocardiographic parameters. Tracings were recorded in six derivations of the frontal plan, with $50 \mathrm{~mm} / \mathrm{s}$ of velocity and sensitivity of $1 \mathrm{~cm}=2 \mathrm{mV}(2 \mathrm{~N})$ in healthy adult conscious guinea pig (Cavia porcellus) using a computerized ECG

\begin{tabular}{lccc}
\hline Parameters* & Mean \pm SD & Min. & Max \\
\hline HR(bpm) & $288.4 \pm 49.7$ & 191.7 & 381 \\
P(ms) & $43.8 \pm 6.46$ & 30 & 60 \\
P(mV) & $0.07 \pm 0.03$ & 0.04 & 0.24 \\
PR(ms) & $66.0 \pm 11.6$ & 41 & 110 \\
QRS(ms) & $63.8 \pm 11.0$ & 41.0 & 91.3 \\
R(mV) & $0.25 \pm 0.16$ & 0.07 & 1.03 \\
T(mV) & $0.06 \pm 0.02$ & 0.03 & 0.13 \\
QT $(m s)$ & $123.9 \pm 16.1$ & 85.7 & 158.7 \\
ST $(m V)$ & $-0.01 \pm 0.08$ & -0.05 & 0.10
\end{tabular}

*Heart rate (HT), duration of the $\mathrm{P}$ wave (Pms), amplitude of $\mathrm{P}$ wave (PmV), duration of the PR segment (PRms), duration of the QRS complex (QRSms), amplitude of R wave (RmV), amplitude of T wave (TmV), duration of QT interval (QTms) and ST segment amplitude (STmV).

Table 3. Electrocardiographic parameters studied in healthy adult conscious guinea pigs (Cavia porcellus) divided in group 1 (500g-699g) and 2 (700g-800g). Tracings were recorded in six derivations of the frontal plan, with $50 \mathrm{~mm} / \mathrm{s}$ of velocity and sensitivity of $1 \mathrm{~cm}=2 \mathrm{mV}(2 \mathrm{~N})$ using a computerized ECG. Data are presented as mean followed by SD

\begin{tabular}{lcc}
\hline Parameters* & Group 1 & Group 2 \\
\hline HR(bpm) & $287.1 \pm 9.30^{\mathrm{A}}$ & $284.7 \pm 10.1^{\mathrm{A}}$ \\
$\mathrm{P}(\mathrm{ms})$ & $42.9 \pm 1.11^{\mathrm{A}}$ & $45.4 \pm 1.21^{\mathrm{A}}$ \\
$\mathrm{P}(\mathrm{mV})$ & $0.07 \pm 0.01^{\mathrm{A}}$ & $0.07 \pm 0.01^{\mathrm{A}}$ \\
$\mathrm{PR}(\mathrm{ms})$ & $66.2 \pm 2.04^{\mathrm{A}}$ & $66.8 \pm 2.21^{\mathrm{A}}$ \\
$\mathrm{QRS}(\mathrm{ms})$ & $65.5 \pm 2.28^{\mathrm{A}}$ & $65.3 \pm 2.47^{\mathrm{A}}$ \\
$\mathrm{R}(\mathrm{mV})$ & $0.23 \pm 0.02^{\mathrm{A}}$ & $0.22 \pm 0.02^{\mathrm{A}}$ \\
$\mathrm{T}(\mathrm{mV})$ & $0.06 \pm 0.01^{\mathrm{A}}$ & $0.06 \pm 0.01^{\mathrm{A}}$ \\
$\mathrm{QT}^{* *}(\mathrm{~ms})$ & $122.6 \pm 3.04^{\mathrm{a}}$ & $124.3 \pm 3.30^{\mathrm{a}}$ \\
$\mathrm{ST}^{* *}(\mathrm{mV})$ & $-0.01 \pm 0.10^{\mathrm{a}}$ & $-0.02 \pm 0.11^{\mathrm{a}}$
\end{tabular}

*Heart rate (HT), duration of the $\mathrm{P}$ wave (Pms), amplitude of $\mathrm{P}$ wave (PmV), duration of the PR segment (PRms), duration of the QRS complex (QRS$\mathrm{ms}$ ), amplitude of $\mathrm{R}$ wave (RmV), amplitude of $\mathrm{T}$ wave (TmV), duration of QT interval (QTms) and ST segment amplitude (STmV).Mean values followed by different superscript letters in the same row are statistically different by Tukey's test $(\mathrm{P} \leq 0.05) .{ }^{* *}$ Mean values followed by different lowercase letters in the same row are statistically different by Kruskal Wallis test $(\mathrm{P} \leq 0.05)$.
Table 4. Electrocardiographic QT duration parameters of adult healthy conscious guinea pigs (Cavia porcellus) using the following formulas: Bazett, Fridericia and Van der Water were recorded in six derivations of the frontal plan, with $50 \mathrm{~mm} / \mathrm{s}$ of velocity and sensitivity of $1 \mathrm{~cm}=2 \mathrm{mV}(2 \mathrm{~N})$ using a computerized ECG. Data are presented as mean and confidence interval of $95 \%$.

\begin{tabular}{lccc}
\hline $\begin{array}{l}\text { Parameters } \\
(\mathrm{ms})^{*}\end{array}$ & Mean and SD & $\begin{array}{c}\text { Confidence } \\
\text { Interval }(\mathrm{ms})\end{array}$ & Correlation \\
\hline QT & $123.9 \pm 0.018^{\mathrm{A}}$ & 172.5 to 182.6 & 1 \\
QTcB & $264.4 \pm 0.034^{\mathrm{B}}$ & 254.8 to 274.1 & 0.81 \\
QTcF & $204.1 \pm 0.026^{\mathrm{C}}$ & 190.5 to 0.016 & 0.93 \\
QTcV & $196.5 \pm 211.7^{\mathrm{D}}$ & 185.7 to 195.2 & 0.98 \\
\hline
\end{tabular}

QTcB = QT*(RR)1/2 (Bazett 1920); QTcF = QT*(RR)1/3(Fridericia 1920) and $\mathrm{QTcV}=\mathrm{QT}+0.087$ (1- RR) (Van de Water et al. 1989). Mean values followed by different superscript letters in the same column are statistically different by Tukey's test $(\mathrm{P} \leq 0.05)$.

between QT and QTcB $(\mathrm{r}=81 ; \mathrm{p}<0.0001)$ and QTcF $(\mathrm{r}=93$; $\mathrm{p}<0.0001)$, but a strong correlation was detected between QT and QTcV ( $r=98 ; \mathrm{p}<0.0001)$. The 95\% confidence interval analysis for the QTcV values was from 185.7 to $195.2 \mathrm{~ms}$ (Table 4). No differences were found between groups using the correction formulas.

\section{Mean electrical axis}

The MEA in the frontal plane presented the same direction in all cases within range from 0 to $60^{\circ}$. The median value corresponded to $30^{\circ}$. No difference was detected among groups (data not showing).

\section{DISCUSSION}

Guinea pig offers a number of advantages in relation to larger animals including lower cost, less variability and a great number of research tools (Akera et al. 1979, Farraj et al. 2011). Anesthetized guinea pig model is effective in early cardiovascular studies to evaluate the effects of drug candidate molecules, but anesthesia has a number of effects on the cardiovascular system and may cause disturbances on the ECG, especially in the QT interval (Hamlin et al. 2003, Morissette et al. 2013). So, the development and application of a noninvasive method for aquisition of ECG tracings in awake animals may present a consistent alternative approach for long-term studies (Pereira-Júnior et al. 2010).

The technological advances provided by computerized ECG have simplified tracings collection in small rodents and facilitated their incorporation into electrophysiology and toxicology studies (Farraj et al. 2011). The measurements have more accuracy and reproducibility than conventional ECG, minimizing restraining time with large storage capacity (Tilley 1992, Camacho et al. 2010). However, this exam has certain limitations with inappropriate arrhythmia diagnosis due to built-in software. Reports describe 7.8\% of error in clinical cases, especially when events of atrial fibrillation occur (Bae et al. 2012). Therefore preliminary software interpretations require reading and confirmation by a qualified eletrocardiographer (Estes 2013).

In the present study, the careful positioning of the animals in a quiet room allowed to optimal immobilization with 
mild restraining, producing valuable recordings. The shape of the waves was similar to those found in literature (Watanabe et al. 1985), were P-QRS-T waves were mainly positive in lead II. ECG results were compared to values found by other authors (Pratt 1938, Zeman \& Wilber 1965, Farmer \& Levy 1968, Pelentz 1971, Wagner \& Manning 1976, Marks et al. 2012). Our HR findings of $288 \mathrm{bpm}$, ranging from 238.68 to $338.10 \mathrm{bpm}$ were similar to values acquired by plate electrodes in conscious animals, found by Farmer \& Levy (1968), that ranged from 240 to $310 \mathrm{bpm}$, and very different from the studies using anesthetized animals: Pratt (1938) that varied from 327 to $400 \mathrm{bpm}$, Marks et al. (2012) $252 \pm 12 \mathrm{bpm}$ and Watanabe et al. (1985) 330bpm.

The PR interval varied from 54.35 to $77.55 \mathrm{~ms}$, with mean value of $65.95 \mathrm{~ms}$, similar to those encountered by Farmer \& Levy (1968) 70ms and Zeman \& Wilber (1965) $54 \mathrm{~ms}$, but very different from Pratt (1938) 162 to 288ms. These discrepancies could be associated with the positioning of the animals: Farmer \& Levy (1968) used sitting unrestrained animals, while Pratt (1938) used animals in the upright position, and Zeman \& Wilber (1965) used animals in pronated position.

The mean electrical axis we found ranged from 0 to $30^{\circ}$, while Pratt (1938) with standing restrained animals found 0 to $76^{\circ}$ and Pelentz (1971) with anesthetized animals found 20 to $80^{\circ}$. These differences can be attributed to age, body weight and thoracic perimeter, as well as the positioning of the heart in the thorax (Tilley 1992).

$\mathrm{P}$ wave is usually positive in lead II corroborant with Pratt (1938), Pelentz (1971) and Watabanabe et al. (1985). No normal range values were found for $P$ wave amplitude for comparison purpose. $\mathrm{P}$ wave duration showed range from 37.3 to $50.3 \mathrm{~ms}$, similar to the values found by Zeman \& Wilber (1965) that ranged from 30 to $60 \mathrm{~ms}$. QRS complex duration varied from 52.7 to $74.8 \mathrm{~ms}$, differing from all the other values found in literature that varied from 13 to 30 ms (Pratt 1938, Farmer \& Levy 1968, Pelentz 1971), from $44.8 \pm 9.5 \mathrm{~ms}$ found by Marks et al. (2012) and $20 \mathrm{~ms}$ found by Watanabe et al. (1985). The mean $\mathrm{T}$ wave found was of $0.06 \mathrm{~ms}$, ranging from 0.04 to 0.08 , while Pelentz (1971) found that $90 \%$ of the animals had $0.01 \mathrm{mV}$ waves. The ST deviation was $-0.01 \pm 0.08$ differing to the finds cited by Wagner \& Manning (1976) that ST deviation was up to $0.05 \mathrm{mV}$. In association with the positioning of the animals, these differences could be explained by the use of anesthetics such as ether (Pelentz 1971, Watanabe et al. 1985) and pentobarbital (Marks et al. 2012).

The QT interval, essential for human drug studies, varied from 107.7 to $140.1 \mathrm{~ms}$, correlating to the findings of 130 ms obtained by Pelentz (1971), 110 ms obtained by Farmer \& Levy (1968), and 107ms by Zeman \& Wilber (1965). QT correction was made using the Bazett, Fridericia and Van der Water formulas, and considering the high HR, QTcV showed less variability from the original QT thus suggesting that the Van der Water formula should be employed. That is in accordance with previous researchers (Spence et al. 1998, Oliveira et al. 2012). The need to establish a suitable QT correction formula relies on the importance to evaluate the occurrence of QT prolongation, which leads to fatal arrhythmias such as Torsade de Pointes (Hamlin et al. 2003).

The differences in the waves' length and amplitudes can be explained by the recording methodology. Some studies used invasive ECG (Zeman \& Wilber 1965), plaque recordings (Farmer \& Levy 1968), mechanical restraining (Pratt 1938) and anesthetized animals (Pelentz 1971), while our study used manually restrained conscious animals with a new electrocardiography acquisition system. QRS complex above the reference values has been described by authors using the present equipment when evaluation ECG from healthy animals. Special attention should be given when assessing these findings (Camacho et al. 2010).

Studies in humans and animals reveal that body weight and obesity can influence ECG tracings (Alpert et al. 2001, Talavera et al. 2008, Neto et al. 2010). In our study, the similarities found while comparing body weight/size of the animals can be attributed to the fact that all animals were standardized and healthy, with no signs of obesity.

\section{CONCLUSIONS}

The present study describes a computerized non-invasive method for surface ECG recordings in conscious guinea pigs.

This study establishes also normal range values for the species and states that Van der Water is the most suitable formula for QT correction.

\section{REFERENCES}

Akera T., Yamamoto S., Chubb J., McNish R. \& Brody T.M. 1979. Biochemical basis for the low sensitivity of the rat heart to digitalis. Naunyn. Schmiedebergs Arch. Pharmacol. 308:81- 88.

Alpert M.A., Terry B.E. \& Hamm C.R. 2001. Effect of weight loss on the ECG of normotensive morbidly obese patients. Chest 119:507-510.

Amani M., Sajad J., Ahmadiasl N., Usefzade N. \& Zaman J. 2013. Effect of HEMADO on level of CK-MB and LDH enzymes after ischemia/reperfusion injury in isolated rat heart. Bio Impacts 3:101-104.

Bae M.H., Lee J.H., Yang D.H., Park H.S., Cho Y., Chae S.C. \& Jun J.E. 2012. Erroneous computer electrocardiogram interpretation of atrial fibrillation and its clinical consequences. Clin. Cardiol. 35:348-353.

Bazett H.C. 1920. An analysis of the time-relations of electrocardiograms. Heart 7:353-367.

Camacho A.A., Paulino J.R.D., Pasconi J.P.E. \& Teixeira A.A.A. 2010. Comparison between conventional and computerized electrocardiography in cats. Arq. Bras. Med. Vet. Zootec. 62:765-769.

Estes N.A. 2013. Computerized interpretation of ECGs: supplement not a substitute. Cir. Arrhythm. Eletrophysiol. 6:2-4.

Farmer J.B. \& Levy G.P. 1968. A simple method for recording the electrocardiogram and heart rate from conscious animals. Brit. J. Pharmacol. Chemother. 32:193-200.

Farraj A.K., Hazari M.S. \& Cascio W.E. 2011. The utility of the small rodent electrocardiogram in toxicology. Toxicol. Sci. 121:11-20.

Fridericia L.S. 1920. Die Systolendauer im Elekstrokardiogramm bei normalen Menschen und bei Herzkranken. Acta Med. Scand. 53:469-486.

Hamlin R.L., Kijtawomrat A., Keene B.W. \& Hamlin D.M. 2003. QT an RR intervals in conscious and anesthetized guinea pigs with highly varying $R R$ intervals and given QTc-lengthening test articles. Toxicol. Sci. 76:437-442.

Harada T., Fumiko I., Hamada M., Horie N., Nitta Y., Karsuoka H. \& Nakamura S. 2010. Circadian rhythm of heart-rate variability and autonomic cardiovascular regulation in Parkinson's disease. Auton. Neurosci. 158: 133-140. 
Malkin R. 1999. Experimental cardiac tachyarrhythmias in guinea pigs. J. Electrocardiol. 32:84-86.

Marks L., Borland S., Philp K., Ewart L., Lainée P., Skinner M., Kirk S. \& Valentin J.P. 2012. The role of anesthetized guinea-pig in the preclinical cardiac safety evaluation of drug candidate compounds. Toxicol. Appl. Pharmacol. 263:171-183.

Morissette P., Nishida M., Trepakova, Imredy J., Lagrutta A., Chaves A., Hoagland K., Hoe C.L., Zrada M.M., Travis J.J., Zingaro G.J., Gerenser P., Friderichs G. \& Salata J.J. 2013. The anesthetized guinea pig: an effective early cardiovascular derisking and lead optimization model. J. Pharmacol. Toxicol. Methods 69:137-149.

Neto G.B.P., Brunetto M.A., Sousa M.G., Aulus C.C. \& Camacho A.A. 2010. Effects of weight loss on the cardiac parameters of obese dogs. Pesq. Vet. Bras. 30:167-171.

Oliveira M.S., Muzzi R.A.L., Muzzi L.A.L., Cherem M. \& Mantovani M.M. 2012. QT interval in healthy dogs: which method of correcting the QT interval in dogs is appropriate for use in small animal clinics? Pesq. Vet. Bras. 34:469-472.

Oliveira M.S., Muzzi R.A.L., Araújo R.B., Muzzi L.A.L., Ferreia D.F. \& Silva E.F. 2014. Heart rate variability and arrhythmias evaluated with Holter in dogs with degenerative mitral valve disease. Arq. Bras. Med. Vet. Zoo. 66:425-432.

Pelentz T. 1971. Electrocardiogram of the guinea-pig. Acta Physiol. Pol. 22:113-121.

Peng S., Yu Y., Hao K., Xing H., Li D., Chen C., Huang A., Hong X., Feng Y., Zhang Y., Li J., Wang B., Wu D., Wang X. \& Xu X. 2006. Heart rate-corrected QT interval duration is significantly associated with blood pressure in Chinese hypertensives. J. Electrocardiol. 39:206-210.

Pereira-Júnior P.P., Marocolo M., Rodrigues F., Medei E. \& Nascimento J.H.M. 2010. Noninvasive method for electrocardiogram recording in conscious rats: feasibility for heart rate variability analysis. An. Acad. Bras. Cienc. 82:431-437.

Pinto M.C., Borboleta L.R., Melo M.B. \& Melo M.M. 2010. Tityus fasciolatus envenomation induced by cardio-respiratory alterations in rats. Toxicon 55:1132-1137.

Pratt C.L.G. 1938. The electrocardiogram of the guinea-pig. J. Physiol. 92:268-272.

Shiotani M., Harada T., Abé J., Sawada Y., Hashimoto K., Hamada Y. \& Hori I. 2005. Practical application of guinea pig telemetry system for QT evaluation. J. Toxicol. Sci.30:239-247.

Spence S., Soper K., Hoe C.M. \& Coleman J. 1998. The heart rate-corrected QT interval of conscious beagle dogs: a formula based on analysis of covariance. Toxicol. Sci. 45:247-258.

Talavera J., Guzman M.J., Del Palacio M.J., Albert A.P. \& Bayón A. 2008. The normal electrocardiogram of four species of conscious raptors. Res. Vet. Sci. 84:119-125.

Tárraga K.M., Spinosa H.S. \& Camacho A.A. 2000. Electrocardiographic evaluation of two anesthetic combinations in dogs. Arq. Bras. Med. Vet. Zootec. 52:138-143.

Tilley L.P. 1992. Essentials of Canine and Feline Electrocardiography: interpretation and treatment. 3rd ed. Lea and Febiger, Philadelphia. 470p.

Van de Water A., Verheyen J., Xhonneux R. \& Reneman R.S. 1989. An improved method to correct the QT interval of the electrocardiogram for changes in heart rate. J. Pharmacol. Toxicol. Methods 22:207-217.

Watanabe T., Rautaharju P.M. \& McDonald T.F. 1985. Ventricular action potentials, ventricular extracellular potentials, and the ECG of guinea pig. Circ. Res. 57:362-373.

Wagner J.E. \& Manning P.J. 1976. The biology of the guinea pig. American College of Laboratory Animal Medicine, Academic Press, New York, NY. $317 \mathrm{p}$.

Zeman F.J. \& Wilber C.G. 1965. Some characteristics of the guinea pig electrocardiogram. Life Sci. 4:2269-2274.

Zimmerman K., Moore D.M. \& Smith S.A. 2015. Hematological assessment in pet guinea pigs (Cavia porcellus): blood sample collection and blood cell identification. Clin. Lab. Med. 35:641-648. 